\title{
Az agrárkereskedelem környezeti hatásainak vizsgálata szisztematikus szakirodalmi áttekintés segítségével
}

\begin{abstract}
A mezőgazdasági és élelmiszeripari termékek 2017-ben a világ teljes exportjából 15 százalékkal részesedtek. A mezőgazdasági alapanyagok aránya a kivitelben megkétszereződött, míg a feldolgozott áruk részesedése megháromszorozódott 2002 óta. A nemzetközi agrárkereskedelem - a határokon átnyúló szennyezéssel, az erdőirtással, az élelmiszer-szállítással és a környezetvédelmi elöírások elkerülésével - sok szempontból növelheti a környezeti externáliákat. Az agrárkereskedelem mértékének jelentősége ellenére a környezet, a kereskedelem és a mezőgazdaság kapcsolatát feltáró tanulmányok száma korlátozott a tudományos szakirodalomban. Jelen tanulmány célja, hogy az elmúlt években publikált nemzetközi közgazdasági szakirodalom szisztematikus bemutatásával áttekintse az agrárkereskedelem környezeti hatásait. A legtöbb vizsgált tanulmány szerint a bővülö kereskedelem, valamint a kereskedelem liberalizációja káros hatást gyakorol a természeti környezetre. A szakirodalom kisebb része állította, hogy az országok természeti környezete profitálhat a kereskedelemből, míg csupán néhány kutató gondolta úgy, hogy a kereskedelemnek egyáltalán nincs jelentős hatása a környezetre. ${ }^{*}$

Journal of Economic Literature (JEL) kód: F18, F14, Q17.
\end{abstract}

$\mathrm{Az}$ agrárkereskedelem jelentősen megnövekedett az elmúlt évtizedekben, globális szinten értéke 2000 és 2016 között évente 6 százalékkal emelkedett (FAO [2018]). Évi 3,1 százalékos növekedéssel a mezőgazdasági termékek bővülése volt a legjelentősebb a kereskedelemben, arányuk 2008 és 2018 között 36 százalékkal emelkedett. A 10 legnagyobb mezőgazdasági exportőr (Európai Unió, Egyesült Államok, Brazília, Kína, Kanada, Indonézia, Thaiföld, India, Ausztrália, Mexikó) a teljes világkivitel 72 százalékát adta 2018-ban (WTO [2019]). A mezőgazdasági termékek kivitelének legjelentősebb

* A kutatás a Nemzeti Kutatási, Fejlesztési és Innovációs Hivatal 128232-es számú, A nemzetközi agrárkereskedelem környezetszennyező hatásainak elemzése című projekt és a 119669-es számú, Globális mezőgazdasági versenyképesség a nemzetközi kereskedelemben című kutatási projektek támogatásával valósult meg. A szerzők ezúton is szeretnék megköszönni a pénzügyi támogatást.

Balogh Jeremiás Máté egyetemi adjunktus, BCE Vállalkozásfejlesztési Intézet (e-mail: jeremias. balogh@uni-corvinus.hu).

Jámbor Attila egyetemi tanár, BCE Vállalkozásfejlesztési Intézet (e-mail: attila.jambor@uni-corvinus.hu). A kézirat első változata 2020. július 1-jén érkezett szerkesztőségünkbe.

DOI: http://dx.doi.org/10.18414/KSZ.2020.9.930 
részarányát Kína (9 százalék), Brazília (6 százalék) és Mexikó (6 százalék) biztosította 2018-ban (WTO [2019]). Az olyan feltörekvő gazdaságok, mint Brazília, Kína, India és Indonézia voltak felelősek a növekedés legnagyobb részéért is, ők 2016-ban a globális exportérték 14,5 százalékát tették ki, szemben a 2000. évi 8,5 százalékos aránnyal (FAO [2018]). A nemzetközi kereskedelem bővülésével párhuzamosan a környezetszennyezés és az éghajlatváltozással kapcsolatos jelenségek globális problémaként jelentkeztek. A nemzetközi kereskedelem elősegítheti a környezeti externáliák kialakulását (a környezetszennyezés fokozódását vagy a természeti erőforrások romlását), és nagyrészt felelös a termelés ösztönzéséért, a határokon átnyúló szennyezésért, az erőforrások nagyarányú kereskedelméért, a növekvő szállításért és a környezetvédelmi elöírások elkerülése érdekében történő termelés áthelyezéséért (Harris [2004]). Ezenkívül a kereskedelem liberalizációja megkönnyítheti a szennyezésintenzív tevékenységekre való specializálódást is (OECD [2019]). Az agrárkereskedelemnek közvetett környezeti hatásai is lehetnek (például a mezőgazdasági termelőket a marginális területekre szoríthatja ki), és nagyobb erdőirtásra ösztönözheti őket az öserdei területeken. Sok fejlődő országban az exportra történő termelés bővülése miatt egyre nő a termelésbe vont termőterületek nagysága. Az ipari hulladékok (például elektromos eszközök) vagy a veszélyeztetett fajok kereskedelme szemmel látható környezeti hatásokkal jár a világban (Harris [2004]). Ezenkívül a kereskedelem bővülése a növekvő környezetszennyezéssel, az üvegházhatást okozó gázok kibocsátásával és az éghajlatváltozással is összefügg. Garsous [2019] kimutatta, hogy a fosszilis tüzelőanyagok égetéséből származó szén-dioxid-kibocsátás 1995 és 2011 között 63 ország és 34 iparág importjában és exportjában szerepelt.

A kereskedelem azonban pozitív hatással is lehet a környezetre. A szabadkereskedelem elösegítheti a hatékonyabb termelés ösztönzését, csökkentheti az energiafelhasználást és javíthatja az új technológiákhoz való hozzáférést (OECD [2019]). Annak ellenére, hogy az agrárkereskedelem szerepe jelentős a világon, a környezet, a kereskedelem és a mezőgazdaság közötti összefüggéseket feltáró tanulmányok általában a mezőgazdaságot a környezetszennyezés potenciális forrásának tekintik. Ezért a jelen tanulmány célja, hogy bővebb áttekintést nyújtson az agrárkereskedelem környezeti hatásairól az 1990 és 2019 között publikált nemzetközi közgazdasági szakirodalom alapján, szisztematikus szakirodalmi áttekintés segítségével.

\section{Anyag és módszer}

Az agrárkereskedelem környezeti hatásainak átfogó áttekintése céljából internetes szakirodalom-keresést végeztünk Moher és szerzötársai [2009] PRISMA-protokoll ${ }^{1}$ módszertana alapján a Scopus-adatbázis (https://www.scopus.com) és a Web of Science (https://apps.webofknowledge.com/) elektronikus tudományos adatbázis-keresők felhasználásával. Az internetes keresésnél az „agrár”, a „kereskedelem” és a „környezet” kulcsszavak angol nyelvü kombinációját (agri; trade; environment) használtuk fel, amelynek a keresett irodalom címében, absztraktjában vagy kulcsszavaiban kellett megjelennie.

\footnotetext{
${ }^{1}$ Preferred Reporting Items for Systematic reviews and Meta-Analyses.
} 
Az egyszerüsítés kedvéért csak angol nyelven írt anyagokat választottunk ki, és kizárólag tudományos folyóiratcikkekre koncentráltunk az elemzésnél (a könyvfejezeteket vagy a teljes könyveket kizártuk az adatbázisunkból). Annak biztosítása érdekében, hogy csak a releváns cikkeket vonjuk be a végső elemzésbe, a Covidence (https://www.covidence. org/) online szoftvert alkalmaztuk a témába nem vágó tanulmányok kiszürése érdekében. A tanulmányok kutatók általi kiszürése egymástól függetlenül zajlott, de a kutatók egymással megbeszélték az esetlegesen egymásnak ellentmondó válaszok tisztázását.

\section{A szakirodalmi áttekintés folyamatának lépései}

A szakirodalom-gyüjtésre 2019 májusában került sor, és az az 1990 és 2019 között megjelent adatbázisra (kizárólag folyóirat-publikációkra) korlátozódott. Az első szakirodalmi keresés során 168 tanulmányt kaptunk, amely 24 duplikációt tartalmazott, ami arra utal, hogy a témában írt cikkek száma általában alacsony. A duplumok eltávolítása után 144 tanulmányt kaptunk. A kezdeti adatbázis felülvizsgálatakor 57 nem releváns tanulmányt zártunk ki. A fennmaradó 87 folyóiratcikket áttekintve végül 65 releváns publikációt azonosítottunk a téma (a mezőgazdaság, a kereskedelem és a klímaváltozás kapcsolata) szempontjából. A további vizsgálatból kizárt cikkekről elmondható, hogy 19 tanulmány nem volt releváns a téma szempontjából, három tanulmány esetén nem állt rendelkezésre a teljes szöveg. Az éghajlatváltozás és a kereskedelem kapcsolatának szempontjából végül 65 tanulmány bizonyult relevánsnak. A szakirodalom áttekintése során alkalmazott forrásgyüjtési és kizárási folyamatot az 1. ábra szemlélteti.

\section{1. ábra}

A szakirodalom feldolgozása során alkalmazott forrásgyüjtési és kizárási folyamat menete
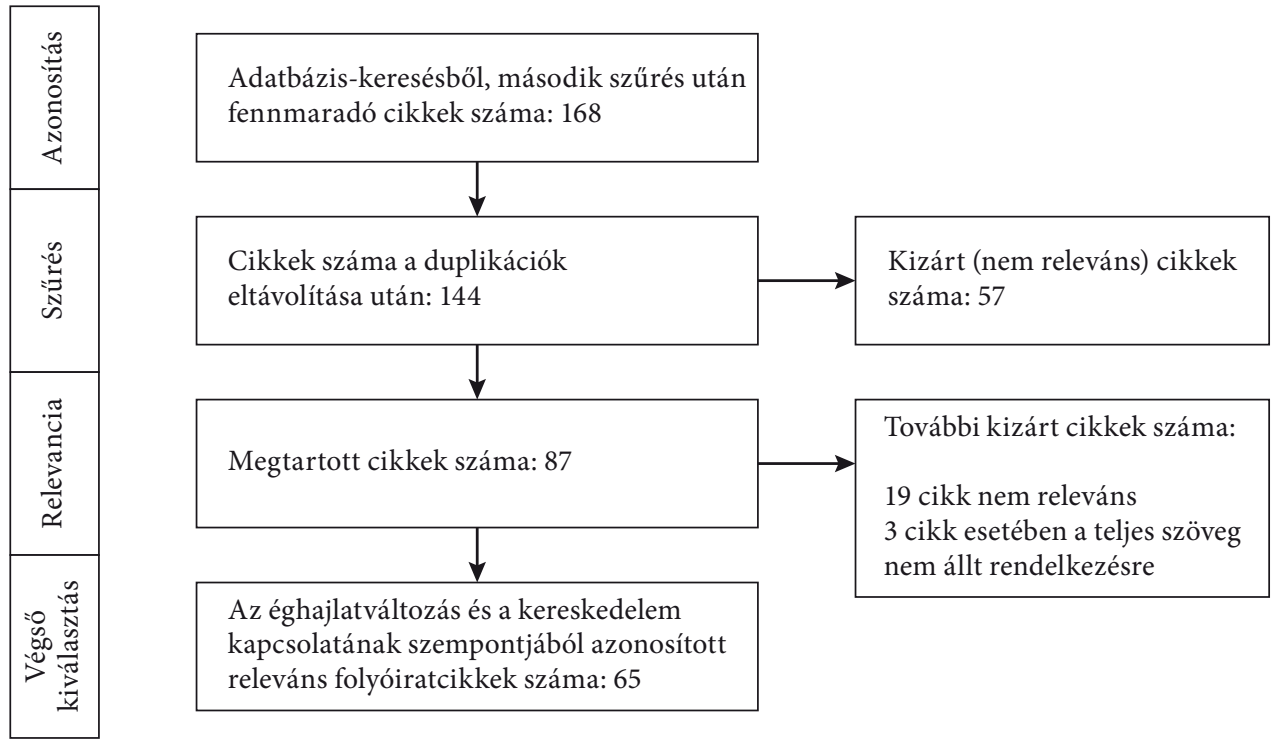

Az éghajlatváltozás és a kereskedelem kapcsolatának szempontjából azonosított releváns folyóiratcikkek száma: 65

Forrás: saját szerkesztés a PRISMA-protokoll módszertana alapján (Moher és szerzőtársai [2009]). 
A 65 relevánsnak bizonyult tanulmány áttekintése alapján 12 kereskedelemmel kapcsolatos kategóriát/témakört hoztunk létre: a tanulmányok jelentős része a kereskedelemmel és az éghajlatváltozással (38 tanulmány), valamint a vízhasználattal (10 tanulmány) foglalkozott. A harmadik leggyakoribb témakör a kereskedelem és az erdőirtás, a földhasználat változása (4 tanulmány), valamint a kereskedelem liberalizációja (3 tanulmány) volt. Ezenkívül olyan, ritkábban előforduló témákat is felfedeztünk, mint például a halászat és a kereskedelem vizsgálata, a kereskedelmi megállapodások, az élelmezésbiztonság, a zöldalga-szennyezés, a nitrogénkereskedelem, a környezetvédelmi szabályozás és a környezetvédelem kapcsolatának témakörei. A 2. ábra az elemzett cikkek alapján alkotott főbb témaköröket mutatja.

2. ábra

A vizsgált folyóiratcikkek föbb témái, 1990-2019

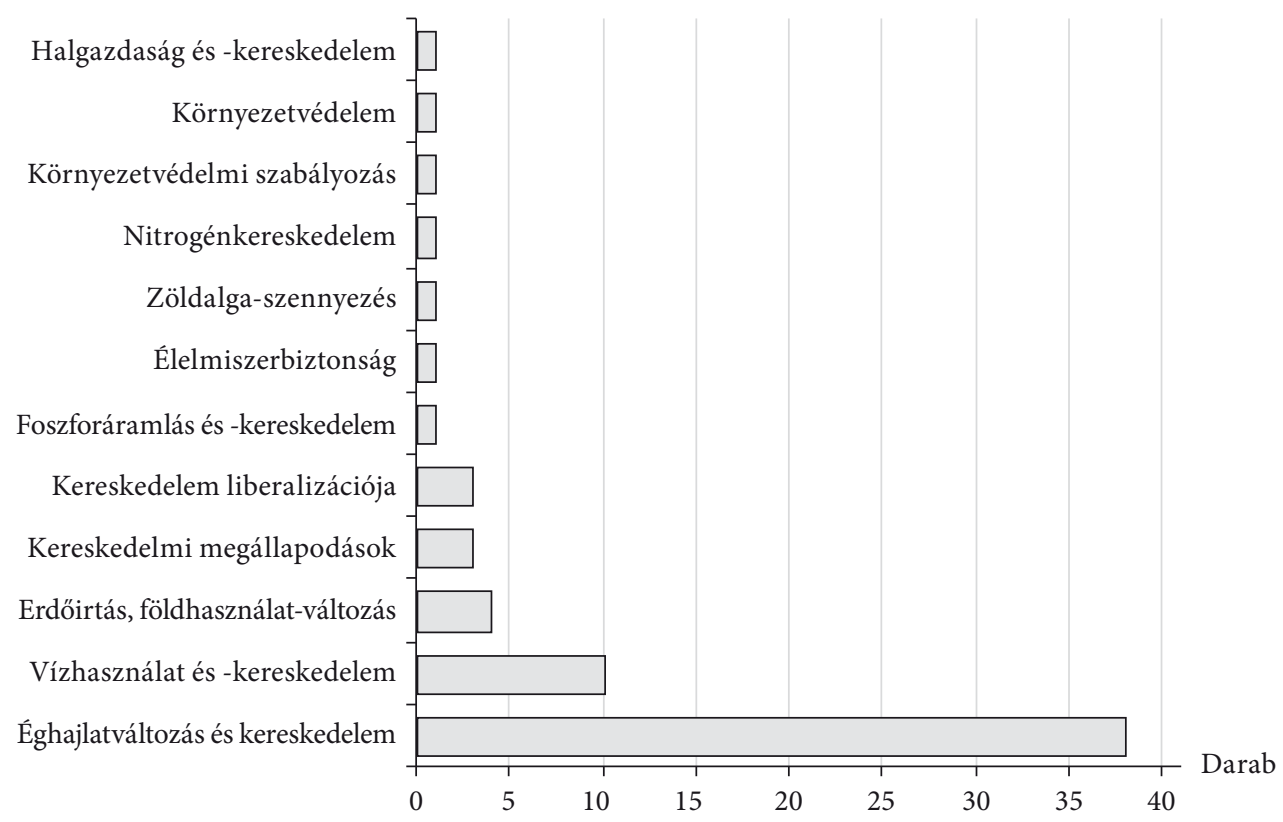

Forrás: Scopus-adatbázis (https://www.scopus.com) alapján saját szerkesztés.

Ami a kiválasztott szakirodalom adatbázisában szereplő országok reprezentációját illeti, a két legnépszerủbb elemzett ország az Egyesült Államok (10) és Kína (9) volt, amelyek esetében a kereskedelem és a környezet viszonyát vizsgálták, őket Mexikó (6), az EU (5) és a dél-amerikai régió (Brazília, Argentína) követte. A legtöbb tanulmány (21) a környezet és a kereskedelem kérdését globális problémaként értelmezte (3. ábra). A globális szintű elemzések mellett ugyanakkor regionális szintű tanulmányok is készültek. 


\section{3. ábra}

Az elemzett országok elöfordulásának gyakorisága a környezet és az agrárkereskedelem kapcsolatával foglalkozó szakirodalomban

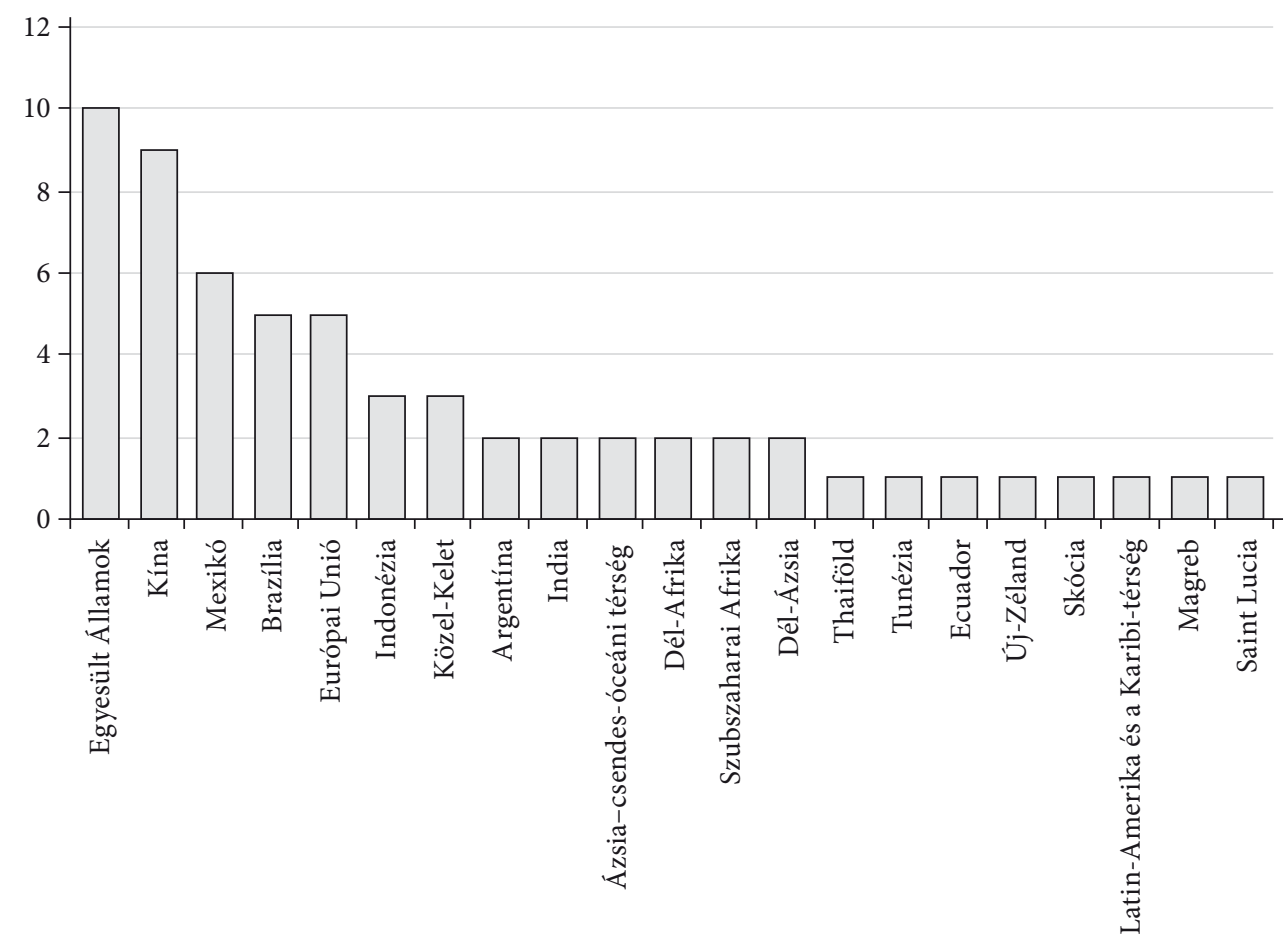

Forrás: Scopus-adatbázis (https://www.scopus.com) alapján saját szerkesztés.

Az elemzett régiók közül három különösen veszélyeztetett régiót vizsgáltak a szakirodalomban: Mato Grosso (Brazília), a Jangce folyó (Kína) és a Hai folyó (Kína) vízgyüjtő területe. Az állattenyésztési és a növénytermesztési ágazatokat a kereskedelemmel kapcsolatos környezetszennyezés potenciális motorjaiként értelmezték. Az állattenyésztést illetően a hús-, a tejtermékek előállítását és a halászati ágazatot említették, a növénytermesztés esetében pedig a kukoricatermesztés, a kertészeti termékek (paradicsom, paprika, uborka), a banánexport, a szójabab, a cukornád, a pálmaolaj, a gumi, a kávé és a zöld algák témakörét elemezték. Végül a vízigényes mezőgazdasági termékek és a biomassza kereskedelme szintén összefüggésbe volt hozható a környezeti problémákkal. A kiválasztott cikkekben alkalmazott módszertan aránya szempontjából a gazdasági modellezés volt a legnépszerübb (66 százalék), amelyet a leíró és grafikus elemzések követtek (14 százalék), míg a kvalitatív technikákat (3 százalék) és az esettanulmányokat (2 százalék) a legkisebb mértékben alkalmazták (4. ábra). 


\section{4. ábra}

A vizsgált szakirodalom által alkalmazott főbb kutatási módszerek megoszlása

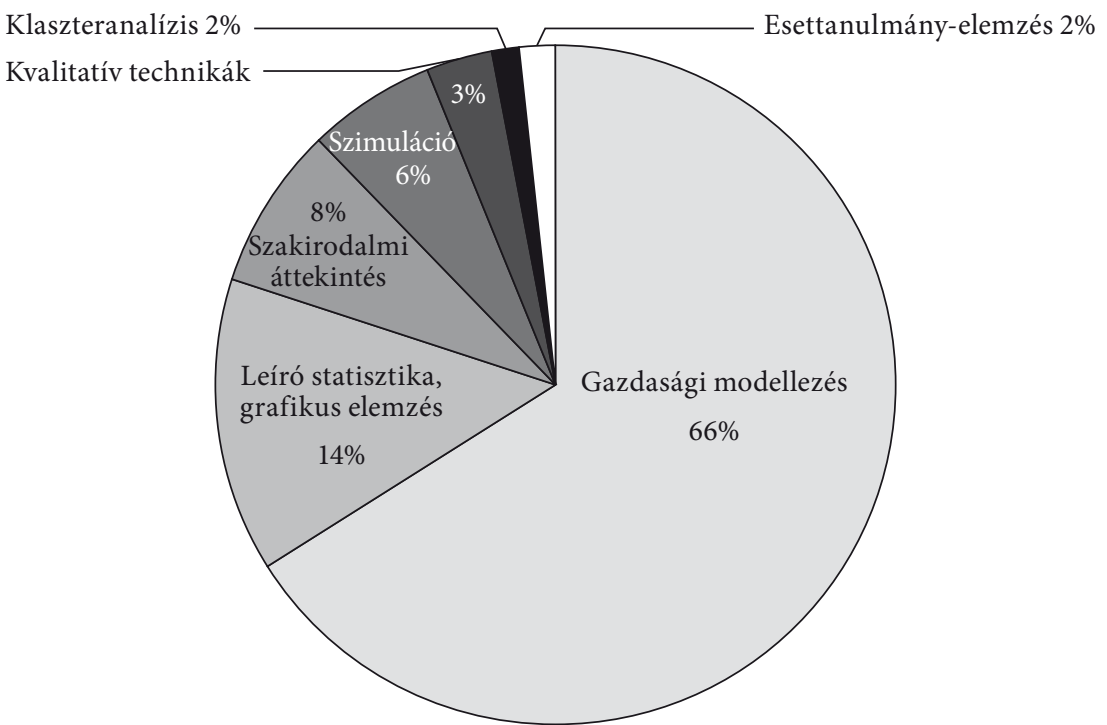

Forrás: a minta adatai alapján saját szerkesztés.

\section{Az agrárkereskedelem különféle környezeti hatásai}

A fent leírt adatbázisból (65 cikk) kitünik, hogy a kiválasztott szakirodalomból származó cikkek három főbb témakör köré csoportosulnak: éghajlatváltozás, vízhasználat és egyéb témakör. A legtöbb tanulmány a kereskedelemmel kapcsolatos éghajlatváltozási kérdésekre (üvegházhatású gázok kibocsátása, erdőirtás, a kereskedelem által elöidézett földhasználat-változás) összpontosított, míg néhányukban a kereskedelemnek a vízszennyezésre és a vízfelhasználására gyakorolt hatását (öntözés, nagy vízigényü termékek kereskedelme, vízkereskedelem) vizsgálták. Végül közülük csak négy foglalkozott az agrárkereskedelemtől eltérő kutatási témákkal, amelyek a következők voltak: a szén-dioxid-kereskedelem Skóciában (Hanley-Brennan [2012]), élelmezésbiztonsági politikák hatása a környezetre, a mezőgazdasági piacok globalizációja (Brown és szerzőtársai [2014]), a fonalas zöld alga szennyezésének hatásai (de Lange és szerzötársai [2016]) és a nitrogénveszteségek csökkentése termelöi szinten (Delgado és szerzőtársai [2008]). A szakirodalmat az általunk készített adatbázisból kiindulva a következő hipotézisek alapján elemeztük és kategorizáltuk az agrárkereskedelem környezetre gyakorolt hatásait figyelembe véve:

- az agrár(szabad)kereskedelem káros a környezetre, környezetszennyezéshez vezet,

- az agrárkereskedelemnek nincs jelentős hatása a környezetre/a szennyezésre,

- az agrárkereskedelem pozitív hatással van a környezetre/csökkenti a szennyezést és

- az agrárkereskedelem negatív vagy pozitív hatást egyaránt gyakorolhat a környezetre és a szennyezésre. 


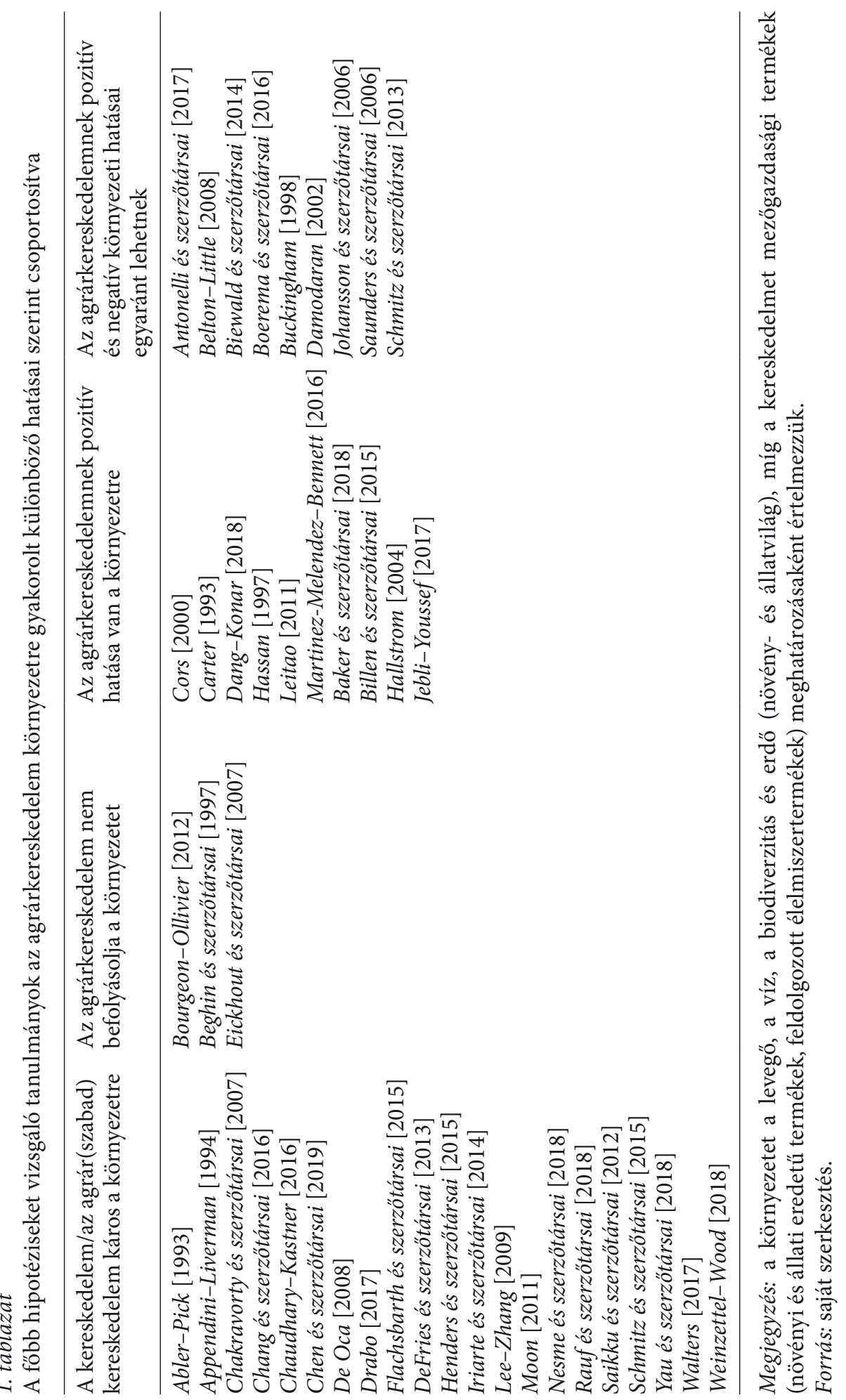


A 65-ből összesen 21 cikk állította, hogy a kereskedelem vagy az agrárkereskedelem károsítja a környezetet és/vagy környezetszennyezéshez is vezet. Más szóval: ezek a cikkek egyértelmüen megállapították, hogy a kereskedelem hozzájárul a környezetszennyezéshez és az éghajlatváltozáshoz (1. táblázat).

\section{Kutatási eredmények}

\section{Az agrárkereskedelem környezetre gyakorolt negatív hatásait elemzö tanulmányok}

Az elemzett szakirodalom legtöbb tanulmánya rámutatott az agrárkereskedelem éghajlatváltozásra gyakorolt negatív hatására. Appendini-Liverman [1994] feltárta, hogy az agrárpolitika és az éghajlati viszonyok miként befolyásolták a kukoricatermelést és az élelmezésbiztonságot Mexikóban. A szerzők szerint a globális felmelegedés veszélyt jelent a helyi és nemzeti élelmezésbiztonságra, ha a gazdák nem képesek alkalmazkodni a szárazabb éghajlathoz, vagy ha a más régiókból történő import megdrágul. Saunders és szerzőtársai [2006] az Új-Zéland és az Európai Unió közötti kétoldalú kereskedelmet vizsgálta, és arra a megállapításra jutott, hogy a kereskedelem liberalizálása Új-Zéland esetében növeli az üvegházhatású gázok kibocsátását, az Európai Unió oldalán pedig csökkenti. Hasonlóképpen, Lee-Zhang [2009] szerint a kereskedelem liberalizációja magasabb energiafelhasználást és szén-dioxid-kibocsátást okozott, ami különösen a szegény fejlődő országokban jelentett problémát. Többek között Schmitz és szerzőtársai [2015] kimutatta, hogy a kereskedelem további liberalizációja az erdőirtás növekedéséhez vezetett Amazóniában. Ezenkívül Lee-Zhang [2009], Schmitz és szerzötársai [2015] és Flachsbarth és szerzőtársai [2015] rámutott, hogy a kereskedelem további liberalizációja a jövőben nagyobb környezeti nyomást okoz majd LatinAmerika egyes régióiban. A fenti szerzők nyomán Moon [2011] vitatta az agrár-szabadkereskedelem pozitív szerepét, és bemutatta, hogy a szabadkereskedelem nem képes megoldani az országok és régiók környezettel kapcsolatos differenciált problémáit. Ezenkívül Raufés szerzötársai [2018] megállapította, hogy a nyitottabb kereskedelem rontotta a környezet állapotát Kínában.

A virtuálisvíz-kereskedelem ${ }^{2}$ környezeti hatásait több cikk is vizsgálta (Zhao és szerzőtársai [2010], Zhangés szerzőtársai [2011]). Egyrészt Zhao és szerzőtársai [2010] kimutatta, hogy az exportált és importált termékekben - különösen a reexport esetében szereplő virtuálisvíz-kereskedelem jelentős mértékben növelte a vízlábnyomot és megbillentette az ökológiai egyensúlyt Kínában. Másrészt Zhang és szerzötársai [2011] szerint Kína nettó virtuálisvíz-exportőr, míg a megújulóenergia-termelés csupán 2,1 százalékát és a világ teljes vízfelhasználásának 8,6 százalékát teszi ki.

A földhasználat-változással összefüggő szén-dioxid-kibocsátásról megállapítható, hogy az éghajlatváltozás egyik fö hajtóerője. Ezenkívül Saikku és szerzőtársai [2012] a biomassza kereskedelmének a földhasználat változására gyakorolt hatását,

\footnotetext{
${ }^{2}$ A virtuális víz fogalma ebben a megközelítésben azt jelenti, hogy figyelembe vesszük a termékek előállításához szükséges csapadék- (zöld) és technológiai (kék) vizet is.
} 
valamint a szén-dioxid-kibocsátást elemezte. A szerzők megállapították, hogy Brazíliában és Indonéziában az összes megmüvelt földterület 15-32 százalékkal bővült a földhasználat változásával kapcsolatos kibocsátás növekedése (szarvasmarhahús- és pálmaolajexport) miatt. Ezen túlmenően DeFries és szerzőtársai [2013] igazolta, hogy a földhasználat megváltoztatásának ökológiai, hidrológiai és társadalmi következményei a trópusi esőerdők egyharmadában leginkább az exportorientált mezőgazdaságra voltak visszavezethetők 2000 és 2005 között. Ökológiai megközelítésben Henders és szerzőtársai [2015] rámutatott, hogy a földhasználat változása és a faanyag iránti globális kereslet növelte az erdőirtás dinamikáját és az exporthoz kapcsolódó szén-dioxid-kibocsátást.

Néhány tanulmányban a banánkereskedelmet is megemlítették a szén-dioxidkibocsátás növekedésének felelöseként. Iriarte és szerzőtársai [2014] megállapította, hogy a karbonlábnyom legfontosabb tényezői a nagyüzemi méretü termelés és a tengerentúli szállítás voltak az Ecuadorból származó banánkivitel esetében. Emellett Walters [2017] arra a következtetésre jutott, hogy kedvező hatással volt a környezetre az, hogy a banánkereskedelmi korlátozások miatt sokan elhagyták a banánültetvényeket. Chang és szerzőtársai [2016] - az agrárkereskedelem környezetre gyakorolt negatív hatásainak vizsgálatával - a trópusi ökoszisztéma nyújtotta szolgáltatásokkal kapcsolatban Brazíliában, Indonéziában, Thaiföldön, Indiában, Malajziában és Vietnamban tárt fel nagymértékü veszteségeket.

Chaudhary-Kastner [2016] a kereskedelem biológiai sokféleségre gyakorolt hatásait elemezve megállapította, hogy globális szinten a teljes fajveszteség 17 százalékát a belföldi fogyasztás növekedése okozta. A legnagyobb fajtaveszteségeket az Indonéziából az Egyesült Államokba és Kínába irányuló kivitel okozta. Ezenkívül a szerzők hozzátették, hogy a magas egy före jutó GDP-jü iparosodott országok általában a trópusi fejlődő országok biológiai sokféleségének legfontosabb nettó importőrei a növényi exporttermékeik előállítása érdekében (a cukornád, a pálmaolaj, a gumi és a kávé kereskedelme nagy hatással van a biológiai sokféleség romlására).

Csak viszonylag kevés tanulmány foglalkozott a húsfogyasztással kapcsolatos kibocsátással. Drabo [2017] kiemelte, hogy az elsődleges nyersanyagok exportjának aránya a mezőgazdasági termelésben növeli az üvegházhatású gázok kibocsátását. Yau és szerzötársai [2018] kimutatta, hogy mivel Hongkong túlnyomórészt importfüggő város, ezért a hongkongi hús- és tejtermékek kereskedelméből és fogyasztásából származó üvegházhatású gázok kibocsátása - a termelési alapú számítások alapján - 2016-ban meghaladta az üvegházhatást okozó gázok tekintetében a város összes kibocsátását.

Chakravorty és szerzőtársai [2007] a fejlődő országok mezőgazdasági iparosodásának és a környezetnek az állattenyésztésre és a szabályozásra összpontosító kapcsolatát vizsgálta. Megállapította, hogy a fejlődő országok mezőgazdasági iparosodásából eredő környezeti problémák jelentős károkat okozhatnak a termelés növekvő intenzitása miatt. A szerzők hangsúlyozták, hogy sürgető lenne a fejlődő országok számára globálisan olyan ellenőrzési és végrehajtási mechanizmusok bevezetésére, amelyek minimalizálják a kereskedelem környezetre gyakorolt káros hatásait. Végül Weinzettel-Wood [2018] és Nesme és szerzőtársai [2018] rámutattak a kereskedelem bővülésének káros hatásaira. Nesme és szerzőtársai [2018] az agrárkereskedelem 
globális foszforáramlásban játszott szerepét elemezte, és megállapította, hogy a kereskedelem hatására 1961 és 2011 között a globális foszforáramlás nyolcszorosára növekedett. Ezenkívül Weinzettel-Wood [2018] a kínai export karbonlábnyomát elemezte, és kimutatta, hogy a kínai belföldi fogyasztás növekedése hozzájárul a nemzetközi kereskedelem karbonlábnyomának a csökkentéséhez.

\section{Az agrárkereskedelem elhanyagolható jelentőségü környezeti hatásait igazoló tanulmányok}

Csak néhány tanulmány (65-ből 4) állította, hogy az agrárkereskedelem nem befolyásolta a környezetszennyezést és ezáltal az éghajlatváltozást. Ervin [1993] az Egyesült Államok példáján a szabadkereskedelem környezeti minőségre gyakorolt hatásait vizsgálta a NAFTA- (Észak-amerikai Szabadkereskedelmi Megállapodás) és a GATT- (Általános Vámtarifa- és Kereskedelmi Egyezmény) megállapodások tükrében. A hasonló kutatásokkal összhangban Beghin és szerzőtársai [1997] nem talált jelentős bizonyítékot a szabadkereskedelem miatt bekövetkezett környezetpusztulásra. Chen és szerzőtársai [2019] kimutatta, hogy az iparágak közötti szövetségek elsősorban a Jangce folyó területéről származó szénkiáramlás előmozdítását szolgálták. A szerzők hangsúlyozták a fogyasztói felelősség szerepét a kereskedelemmel kapcsolatos kibocsátás csökkentésében. Végül Bourgeon-Ollivier [2012] arra a következtetésre jutott, hogy a kereskedelem liberalizálása a regionális komparatív előnyök függvényében - az országok egyéni önellátási szintjéhez viszonyítva - világszerte növelhette is vagy csökkenthette is a szén-dioxid-kibocsátást.

\section{Az agrárkereskedelemnek pozitív (elönyös) hatása van a környezetre}

A cikkek második legnagyobb csoportja (10 tanulmány) azzal érvelt, hogy az agrárkereskedelem bizonyos esetekben pozitív hatással is lehet a környezetre, és hozzájárulhat a környezetszennyezés csökkentéséhez. Carter [1993] kimutatta, hogy az élelmiszer-termelésnek a gazdagból a szegény országokba történő áthelyezése csökkentené a globális mezögazdasági szennyezést, ezért a szabadabb kereskedelem környezetbarátnak tekinthetö. Ehhez Hassan [1997] hozzátette, hogy a mezőgazdasági termékek kereskedelmének liberalizációja a környezeti állapot javulásához vezetett, mivel azok elóállítása pozitív környezeti externáliákkal járhat. Leitao [2011] az Egyesült Államok és partnerországai ágazaton belüli kereskedelmét elemezve negatív összefüggést mutatott ki a szén-dioxidkibocsátás és az iparágon belüli kereskedelem között, és igazolta, hogy az iparágon belüli kereskedelem kevésbé szennyezi a környezetet. Billen és szerzőtársai [2015] hangsúlyozta, hogy a régiók közötti kereskedelem kisebb intenzitása általában kevesebb nitrogénveszteséget okoz, és javítja a mezőgazdasági teljesítményt. Cors [2000] megerösítette, hogy a kereskedelmi és környezetvédelmi megállapodások kölcsönösen támogatják egymást, de ehhez a nemzetközi szintủ megállapodások lényeges harmonizációjára van szükség. Martinez-Melendez-Bennett [2016] rámutatott arra, hogy az amerikai és mexikói 
növénykereskedelem csökkentette a két ország közötti mezőgazdasági kereskedelem okozta környezeti terhelést. Jebli-Youssef [2017] kutatásaikban bemutatta, hogy a nemzetközi gazdasági kereskedelem növekedése új lehetöségeket adott a tunéziai mezőgazdaság számára a megújuló energiaforrások technológiájának átviteléhez és előnyeinek kihasználásához, lehetővé téve versenyképességük fokozását a nemzetközi piacokon és a kisebb szennyezőanyag-kibocsátást. Az éghajlatváltozás hatásainak felmérésével Baker és szerzötársai [2018] Globiom-modellje (Global Biosphere Management Model) szerint a szabadkereskedelem fontos szerepet játszhat a regionális termésingadozás okozta sokkok tompításában az Egyesült Államok mezőgazdaságában és a világ többi részén. Hasonlóképpen: Dang-Konar [2018] bebizonyította, hogy a kereskedelem nyitottsága csökkentette a vízfelhasználást a mezőgazdaságban, ezáltal a természeti erőforrások felhasználását. Végül Hallstrom [2004] szerint a kereskedelem szerepe nagy jelentőségü lehetne az éghajlat-előrejelzés lehetséges előnyeinek a kiaknázásában.

\section{Az agrárkereskedelem vegyes hatása a környezetre}

Összességében kilenc tanulmány (Buckingham [1998], Damodaran [2002], Johansson és szerzőtársai [2006], Eickhout és szerzőtársai [2007], Schmitz és szerzötársai [2013], Boerema és szerzötársai [2016], Biewald és szerzőtársai [2014], Antonelli és szerzőtársai [2017], Belton-Little [2008]) hívta fel arra a figyelmet, hogy az agrárkereskedelemnek kétirányú - pozitív vagy negatív - hatása is lehet a környezetre, elsősorban a környezetvédelmi elöírásokra és a politikai szabályozásra hivatkozva.

Buckingham [1998] a környezetvédelmi intézkedések történelmi fejlödését és kezelését tanulmányozta a Kereskedelmi Világszervezet (World Trade Organization, WTO) keretein belül az Egyesült Államok, Mexikó, Kanada és az EU között. A tanulmány szerint a holtpontra jutott kereskedelmi, környezetvédelmi vitát úgy lehet hatékonyan lefolytatni, hogy - kevésbé versengő módon - inkább az ökoszisztéma egészének javítására összpontosítanak, miközben a nemzetközi piacra jutást és a kereskedelmi kapcsolatok fejlesztését is figyelembe veszik.

Damodaran [2002] hangsúlyozta a nemzeti és globális környezetvédelmi szabályok integrálásának fontosságát a kereskedelemmel kapcsolatos környezetvédelmi szabályozásokba a fejlődő országok fenntartható mezőgazdaságának érdekében. Ezen túlmenően rámutatott arra, hogy a biodiverzitás megőrzését intézményesíteni kellene a nemzeti törvények és a helyi közösségek beavatkozási lehetöségeinek bővítésével. Kritikus fontosságú lenne a nemzeti és a globális környezetvédelmi problémák kezelésének integrálása a kereskedelemmel kapcsolatos környezetvédelmi elöírásokba.

Többek között Johansson és szerzőtársai [2006] elemezte azt, hogy az agrárpolitika okozta torzítások kiküszöbölése hogyan befolyásolja a globális agrárkereskedelem liberalizációját, valamint az Egyesült Államok környezeti minőségét. Megállapításai azt sugallják, hogy a kereskedelmi sokkokból származó környezeti hatások - az átlagos éves ingadozások keretein belül - régiók és ágazatok szerint eltérőek lehetnek. Eickhout és szerzőtársai [2007] szerint a környezetvédelmi és kereskedelmi megállapodásokat megfelelően kellene integrálni vagy összehangolni a környezet javítása 
és a szabadkereskedelem előnyeinek kiaknázása érdekében. Schmitz és szerzőtársai [2013] negatív hatásként mutatta ki Dél-Ázsiában, Délkelet-Ázsiában és a Közel-Keleten a kereskedelem liberalizációjával összefüggő fokozódó vízhiányt és a vízárak csökkenését. A szerzők azt a javaslatot fogalmazták meg, hogy a fejlett országokban csökkenteni kellene az állattartás arányát, és ezzel csökkenthetök lennének a környezeti problémák. A negatív hatások között emelték ki a szójababtermesztés növekvő káros hatásait (erdőirtás és a legelők átalakítása miatt) a főbb exportőr országokban (főleg Brazíliában és Argentínában), valamint az importáló régiókban. Boerema és szerzőtársai [2016] szerint egy-egy régió fogyasztásszerkezetének változása hatással van az ökoszisztéma-szolgáltatások széles területi skálájára.

Viszonylag kevés cikk foglalkozott a kereskedelem és a vízfelhasználás kapcsolatával (Belton-Little [2008], Biewald és szerzőtársai [2014], Antonelli és szerzőtársai [2017]). A Közel-Kelet és Dél-Ázsia példáján Biewald és szerzőtársai [2014] kimutatta, hogy leginkább azok az országok profitálnak a kereskedelemből, amelyek vízigényes növényeket importálnak Dél-Európából. Továbbá a vízhiányos területekről a vízigényes mezőgazdasági termékek exportálása növeli a vízhiányt. Az EU-n belüli agrárkereskedelem és a virtuálisvíz-áramlás kutatása kapcsán Antonelli és szerzőtársai [2017] arra a következtetésre jutott, hogy a nemzetközi agrárkereskedelem befolyásolta a vízgazdálkodást, az EU-ban a virtuálisvíz-kereskedelem piacát csupán néhány ország uralja. Belton-Little [2008] bebizonyította, hogy mind a fenntartható, integrált haltenyésztés, mind a fenntarthatatlanul intenzív belföldi garnélarák-tenyésztés Thaiföldön a globalizáció következményeként jött létre.

\section{A NAFTA hatása a környezetre}

Mindössze két cikk elemezte a NAFTA környezeti hatásait az Egyesült Államok és Mexikó közötti kereskedelem tekintetében. Abler-Pick [1993] arra a következtetésre jutott, hogy a NAFTA csekély mértékben károsan érintette a mexikói kertészeti ágazatot, míg előnyös volt az Egyesült Államok számára. De Oca [2008] szerint a NAFTA fokozta az energiakereskedelmet, az üvegházhatású gázok kibocsátását, míg a fokozott kukoricakereskedelem jelentős erdőirtást és biodiverzitás-veszteséget okozott Mexikóban. Összességében a NAFTA inkább káros hatással járt Mexikó természeti környezetére, míg kedvezőbbnek bizonyult az Egyesült Államok számára.

\section{A szabadkereskedelem negatív hatásai a környezetre}

A szerzők a környezetszennyezés számos tényezőjét említették a szabadkereskedelemnek a környezetre gyakorolt negatív következményeként (2. táblázat). Az üvegházhatást okozó gázkibocsátás fokozódása, a mütrágya fokozott felhasználása, a helyi és nemzeti élelmezésbiztonság fenyegetettsége, a trópusi erdőirtás és a biológiai sokféleség csökkenése, az őserdei területeken zajló, bővülő mezőgazdasági tevékenység, a felszín alatti vizek kimerülése és a szárazabb éghajlat. 


\section{2. táblázat}

A kereskedelem által okozott környezeti problémák

\begin{tabular}{|c|c|c|}
\hline $\begin{array}{l}\text { A kereskedelem által okozott } \\
\text { főbb következmények és éghajlati } \\
\text { veszélyek }\end{array}$ & $\begin{array}{l}\text { Országok és régiók, ahol } \\
\text { a kereskedelem leginkább } \\
\text { környezeti problémákat okoz }\end{array}$ & $\begin{array}{l}\text { A kereskedelem pozitív } \\
\text { környezeti hatásának föbb } \\
\text { haszonélvezői }\end{array}$ \\
\hline $\begin{array}{l}\text { Az üvegházhatást okozó gázok } \\
\text { kibocsátásának növekedése } \\
\text { Fokozott műtrágyahasználat, ami } \\
\text { veszélyezteti a helyi és nemzeti } \\
\text { élelmezésbiztonságot } \\
\text { Jelentős környezetromlás } \\
\text { Erdőirtás, trópusi erdőirtás és } \\
\text { a biodiverzitás csökkenése } \\
\text { A szegényebb területeken élő } \\
\text { és a nagybirtokos termelők } \\
\text { mezőgazdasági tevékenységének } \\
\text { kiterjesztése az esőerdős } \\
\text { területekre } \\
\text { Felszín alatti vizek kimerülése } \\
\text { Fajok elvesztése } \\
\text { Szárazabb éghajlat } \\
\text { Egyre nagyobb helyi vízhiány }\end{array}$ & $\begin{array}{l}\text { OrszÁGoK } \\
\text { Kína, Indonézia, Mexikó, } \\
\text { Brazília (Amazónia), Thaiföld, } \\
\text { Uj-Zéland, India, Brazília, } \\
\text { Malajzia és Vietnam } \\
\text { RÉGıók } \\
\text { A szegény fejlődő országok, } \\
\text { Magreb, } \\
\text { Közel-Kelet, } \\
\text { A Szaharától délre fekvő afrikai } \\
\text { területek, } \\
\text { Latin-Amerika }\end{array}$ & $\begin{array}{l}\text { ORszÁGOK } \\
\text { Európai Unió, Egyesült } \\
\text { Államok } \\
\text { RÉGiók } \\
\text { Fejlett országok, } \\
\text { Közel-Kelet, } \\
\text { Dél-ázsiai országok }\end{array}$ \\
\hline
\end{tabular}

Forrás: saját szerkesztés.

A legnagyobb mértékben érintett országok a kutatások szerint a szegényebb fejlődő országok voltak (Kína, Indonézia, India, Mexikó, Brazília/Amazónia, Thaiföld, Malajzia, Vietnam, Magreb, a Közel-Kelet, Afrika Szaharától délre fekvő területei és Latin-Amerika). Ezzel szemben elsősorban a fejlett országok, mint például az Európai Unió országai, az Egyesült Államok részesültek leginkább a kereskedelem pozitív környezeti hatásaiból.

Az elemzett irodalom azt is tárgyalta, hogy mely mezőgazdasági tevékenységek felelösek a nemzetközi agrárkereskedelem negatív környezeti hatásaiért (3. táblázat).

Egyrészt a cikkek többsége a fogyasztókkal vagy a fogyasztási lehetőségekkel foglalkozott, mivel azok fontos meghatározói voltak a kereskedelem és a környezetszennyezés összefüggésének. Másrészt, a kereskedelemmel kapcsolatos környezetvédelmi elöírások szintén alapvető szerepet játszottak a környezet romlásának mértékében. A kiválasztott szakirodalmi forrásokban különféle megoldásokat javasoltak a kereskedelemmel kapcsolatos szennyezés csökkentésére. Elöször, az Egyesült Államoknak és Kínának együtt kellene müködnie a mezőgazdasági eröforrások védelme érdekében (Brown-Halweil [1998]). Másodszor, új és fenntartható technológiákat kell bevezetni, fejleszteni kell a precíziós mezőgazdaságot - a modern természeti erőforrás-gazdálkodás enyhítheti a kereskedelem káros hatásainak erősödését (Flachsbarth és szerzőtársai [2015]). A káros hatások csökkentése érdekében a mezőgazdasági szektor $\mathrm{K}+\mathrm{F}$-beruházásainak ösztönzésére is szükség van - kutatni kellene a tápanyagellátás hatásait, a növényi kártevőket, a vizet és a talajjavítás lehetőségeit, valamint a növények biológiai potenciáljának 


\section{3. táblázat}

A szennyező tevékenységek és a kereskedelem környezeti hatásainak enyhítésére szolgáló megoldások

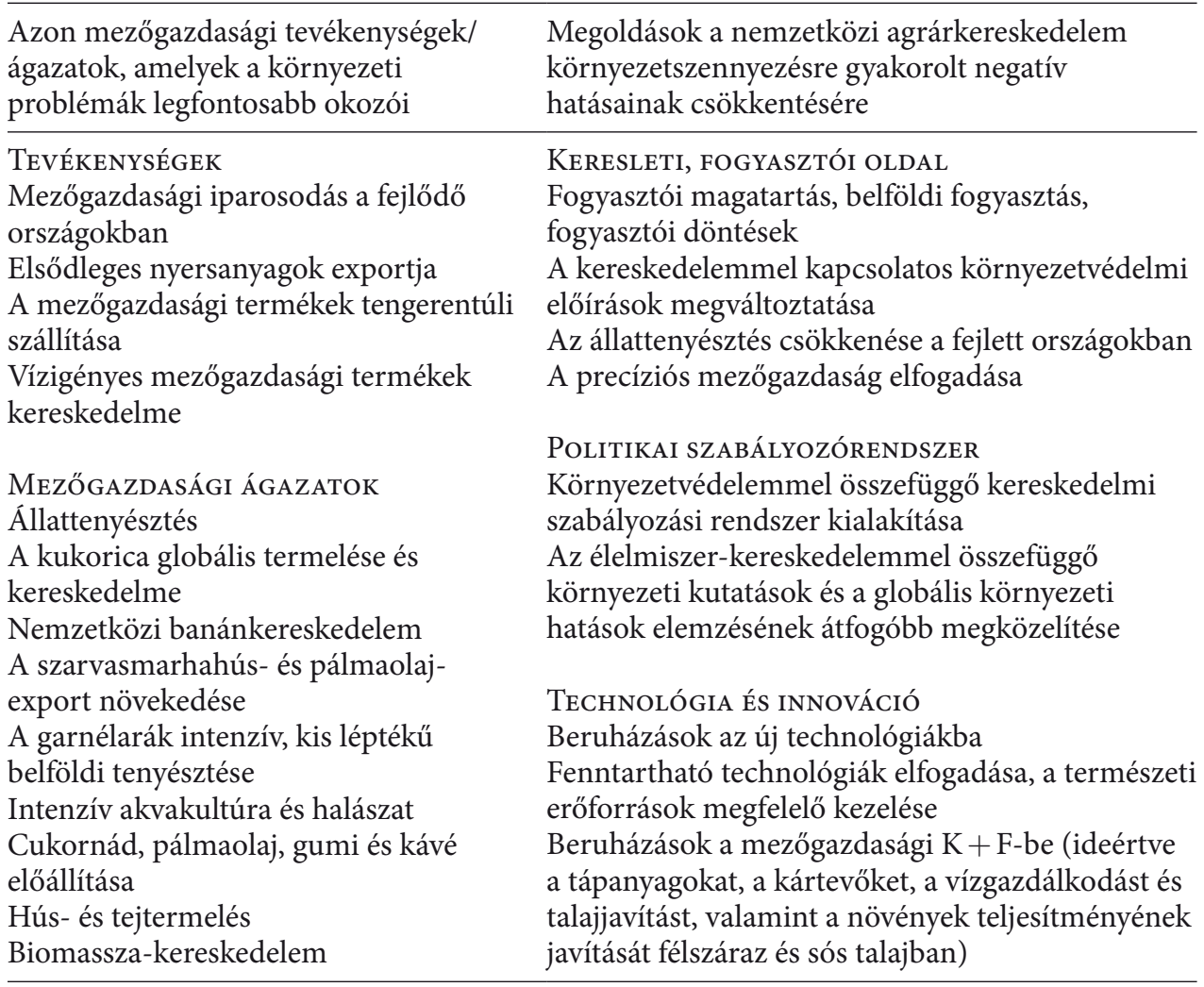

Forrás: saját szerkesztés.

fokozottabb kihasználását félszáraz és sós talajokban (Flachsbarth és szerzötársai [2015]). Dalin-Rodríguez-Iturbe [2016] szerint egyre sürgetőbb egy átfogóbb megközelítés az élelmiszer-kereskedelem környezetre gyakorolt globális hatásának becslésére, a természeti erőforrások értékelésének pontosabb vizsgálatára, valamint az élelmiszerkereskedelem helyi és regionális társadalmi-gazdasági összefüggéseinek elemzésére. Végül, de nem utolsósorban az erdőirtás és a felszín alatti vizek kimerülésének értékeléséhez egy jól alkalmazható elemzési módszertanra lenne szükség.

\section{Következtetések}

A kutatás az agrárkereskedelem környezeti hatásait vizsgálta az 1990 és 2019 eleje között publikált, releváns szakirodalom szisztematikus átvizsgálása alapján. A legtöbb tanulmány a bővülö globális agrárkereskedelem vagy a kereskedelem liberalizációjának a környezetre gyakorolt pozitív szerepével szemben foglalt állást. Csak kisszámú tanulmány 
állította, hogy az egyes országok természeti környezete profitálhat is a szabadkereskedelemből vagy a kereskedelem bővüléséből. Néhány szerző hangsúlyozta, hogy az iparágon belüli és a régiók közötti kereskedelem általában kevesebb környezetszennyezést okozhat világszinten, mint az iparágak közötti kereskedelem.

Csupán kevés tanulmány hangsúlyozta, hogy a kereskedelemnek egyáltalán nem lenne szignifikáns hatása, vagy esetleges kétirányú (pozitív vagy negatív) hatása lenne a környezetszennyezésre. Az Egyesült Államok, Kína, Mexikó és Brazília voltak azok a legnépszerübb országok, amelyeket a kereskedelem és a természeti környezet kapcsolata szempontjából leggyakrabban elemzett a szakirodalom. A vizsgált szakirodalom szerint az egyes növénytermesztési ágazatok (kávé-, szójababtermesztés és pálmaolaj-, gumi-, bioüzemanyag-termelés), az állattenyésztés és az élelmiszeripar (hús, szarvasmarhahús, tejtermékek és halászat) számos országban egyaránt felelősek voltak a környezet pusztulásáért. Az agrár-élelmiszeripari termékek gyorsuló ütemü bővülésével kapcsolatos legfontosabb környezeti problémákként a talajeróziót, a túlzott mezőgazdasági vízfelhasználást, a vízhiányt, az erdőirtást és a biológiai sokféleség csökkenését említette a szakirodalom. A kereskedelem liberalizációjának következményeként fokozott vízhiány volt kimutatható Dél-Ázsiában, Délkelet-Ázsiában és a Közel-Keleten, valamint Brazíliában és Argentínában. A növekvő szójatermelés, az erdőirtás és a legelők bővítésének a negatív hatásai is kimutathatók voltak a föbb agrárexportőr országokban, amelyekért a legfőbb élelmiszer-importáló országok voltak a felelősek.

Az üvegházhatású gázok növekvő kibocsátása és a fokozódó mütrágya-felhasználás szintén a kereskedelem gyorsulásának jelentős következményeiként tarthatók számon. Számos fejlődő országban - Brazíliában, Indiában, Indonéziában és Szubszaharai Afrika területein - a trópusi erdőirtást és a biológiai sokféleség csökkenését, az intenzív mezögazdasági tevékenységeket nevezték meg föbb környezeti problémaként. Ezenfelül a talajvízkészletek kimerülése, bizonyos fajok kihalása és a szárazabb éghajlat egyaránt a kereskedelemmel összefüggő szennyezés legfontosabb következményei voltak a fejlődő világban (főleg Afrikában és Dél-Amerikában). A NAFTA környezetvédelmi szerepét vizsgáló cikkek kimutatták, hogy a megállapodás meglehetősen káros volt Mexikó mezőgazdasága, míg inkább elönyös az Egyesült Államok számára.

A szakirodalom számos lehetséges megoldást is javasolt a kereskedelemmel kapcsolatos környezetszennyezés mértékének a csökkentésére. Emellett rámutatott arra is, hogy az egyik régióban a fogyasztási szokások változása valódi hatást gyakorolhat az ökoszisztéma-szolgáltatások romlására vagy javulására. Különösen a fejlett országok, mint például az Európai Unió vagy az Egyesült Államok részesülnek a legnagyobb mértékben az agrárkereskedelem kedvező környezeti hatásaiból. Ezért fogyasztói szempontból a kutatók azt hangsúlyozták, hogy az állati eredetü termékek fogyasztásának csökkentése a fejlett országokban jelentősen hozzájárulhat a környezetszenynyezés csökkentéséhez, és mindez pozitív hatással lehet a fejlődő országok természeti környezetére is. A szerzők a globalizált kereskedelem pozitív hatásaként említették a környezetvédelem fejlesztését, a megújuló energia növekvő arányú felhasználását, a technológiaátadást és a fenntartható integrált mezőgazdasági technológiákat. 
Termelési szempontból az új technológiákba történő beruházások vagy a precíziós mezögazdaság arányának növelése, valamint a fenntartható technológiák és a természeti erőforrásokkal való megfelelő gazdálkodás enyhítheti az agrárkereskedelem negatív hatásainak növekedését. Ezenkívül a jövőben növelni kellene a mezőgazdasági kutatás-fejlesztési beruházások arányát (ideértve a tápanyagokkal, a kártevőkkel, a fenntartható víz- és talajgazdálkodással kapcsolatos, valamint a növények - félszáraz és sós talajok esetén - termőképességének javítását szolgáló $\mathrm{K}+\mathrm{F}$-beruházásokat).

Emellett a szakpolitikának a környezet minőségének javítása érdekében nemzetközi kereskedelmi egyezményekbe kellene integrálnia a környezetvédelmi megállapodásokat.

Ugyanakkor fontos megemlíteni, hogy manapság a világ élelmiszer-fogyasztását egyszerre jellemzi a túlfogyasztás, az élelmiszer-pazarlás és a hiány. A globális agrárkereskedelem kedvezötlen környezeti hatásait akkor lehetne eredményesen csökkenteni, ha a fejlett országokban sikerülne visszaszorítani az élelmiszer-túlfogyasztást, illetve a hús és az állati eredetű termékek fogyasztását, míg a fejlődő világban létrejöhetnének olyan élelmiszer-ellátó hálózatok, amelyek képesek a gyorsan növekvő népesség élelmiszerigényeit kielégíteni. Malak-Rawlikowska és szerzőtársai [2019] szerint esetleges megoldásként említhetök a rövid ellátási láncok (short supply chain), amelyek a termelökre nézve előnyösek ugyan, de egyértelmü hosszú távú pozitív környezeti hatásaik még nem bizonyíthatók.

Magyarországon a fenntarthatóság iránt elkötelezett és ezért magasabb árat fizetni hajlandó fogyasztók számára lehet jelentőségük a rövid ellátási láncoknak (Török-Agárdi [2020]), de paradox módon elöállhat akár olyan helyzet is, amikor a hagyományos élelmiszeripar a rövid ellátási láncoknál környezetbarátabb megoldást kínál (Benedek [2014]).

\section{Hivatkozások}

Abler, D. G.-Pick, D. [1993]: NAFTA, agriculture, and the environment in Mexico. American Journal of Agricultural Economics, Vol. 75. No. 3. 794-798. o. https://doi. $\operatorname{org} / 10.2307 / 1243594$.

Antonelli, M.-TAmea, S.-YANG, H. [2017]: Intra-EU agricultural trade, virtual water flows and policy implications. Science of the Total Environment, Vol. 587-588. 439-448. o. https://doi.org/10.1016/j.scitotenv.2017.02.105.

Appendini, K.-Liverman, D. [1994]: Agricultural policy, climate change and food security in Mexico. Food Policy, Vol. 19. No. 2. 149-164. o. https://doi.org/10.1016/03069192(94)90067-1.

Baker, J. S.-Havlík, P.-Beach, R.-Leclère, D.-Schmid, E.-Valin, H.-Cole, J.-Creason, J.OHrel, S.-McFarland, J. [2018]: Evaluating the effects of climate change on US agricultural systems: sensitivity to regional impact and trade expansion scenarios. Environmental Research Letters, Vol. 13. No. 6. https://doi.org/10.1088/1748-9326/aac1c2.

Beghin, J.-Dessus, S.-Roland-Holst, D.-Van der Mensbrugghe, D. [1997]: The trade and environment nexus in Mexican agriculture. A general equilibrium analysis. Agricultural Economics, Vol. 17. No. 2-3. 115-131. o. https://doi.org/10.1111/j.1574-0862.1997.tb00468.x. 
Belton, B.-Little, D. [2008]: The development of aquaculture in central Thailand: Domestic demand versus export-led production. Journal of Agrarian Change, Vol. 8. No. 1. 123-143. o. https://doi.org/10.1111/j.1471-0366.2007.00165.x.

BENEDEK ZsófIA [2014]: A rövid ellátási láncok hatásai. MTA KRTK Közgazdaság-tudományi Intézet. Mühelytanulmányok MT-DP, No. 8. Budapest. http://econ.core.hu/file/download/ mtdp/MTDP1408.pdf.

Biewald, A.-Rolinski, S.-Lotze-Campen, H.-Schmitz, C.-Dietrich, J. P. [2014]: Valuing the impact of trade on local blue water. Ecological Economics, Vol. 101. 43-53. o. https:// doi.org/10.1016/j.ecolecon.2014.02.003.

Billen, G.-Lassaletta, L.-Garnier, J. [2015]: A vast range of opportunities for feeding the world in 2050: Trade-off between diet, N contamination and international trade. Environmental Research Letters, Vol. 10. No. 2. https://doi.org/10.1088/1748-9326/10/2/025001.

Boerema, A.-Peeters, A.-Swolfs, S.-Vandevenne, F.-Jacobs, S.-Staes, J.-Meire, P. [2016]: Soybean trade: Balancing environmental and socio-economic impacts of an intercontinental market. Plos One, Vol. 11. No. 5. https://doi.org/10.1371/journal.pone.0155222.

Bourgeon, J. M.-Ollivier, H. [2012]: Is bioenergy trade good for the environment? European Economic Review, Vol. 56. No. 3. 411-442. o. https://doi.org/10.1016/j.euroecorev. 2011.11.002.

Brown, C.-Murray-Rust, D.-Van Vliet, J.-Alam, S. J.-Verburg, P. H.-Rounsevell, M. D. [2014]: Experiments in globalisation, food security and land use decision making. Plos One, Vol. 9. No. 12. https://doi.org/10.1371/journal.pone.0114213.

Brown, L. R.-Halweil, B. [1998]: China's water shortage could shake world food security. World Watch, Vol. 11. No. 4. 10-21. o.

Buckingham, D. E. [1998]: Does the World Trade Organization care about ecosystem health? The case of trade in agricultural products. Ecosystem Health, Vol. 4. No. 2. 92-108. o. https://doi.org/10.1046/j.1526-0992.1998.00077.x.

CARTER, C. A. [1993]: Trade, agriculture, and the environment in developing countries: Discussion. American Journal of Agricultural Economics, Vol. 75. No. 3. 801-802. o. https:// doi.org/10.2307/1243596.

Chakravorty, U.-Fisher, D. K.-Umetsu, C. [2007]: Environmental effects of intensification of agriculture: livestock production and regulation. Environmental Economics and Policy Studies, Vol. 8. No. 4. 315-336. o. https://doi.org/10.1007/BF03353963.

Chang, J.-Symes, W. S.-Lim, F.-CARRAsco, L. R. [2016]: International trade causes large net economic losses in tropical countries via the destruction of ecosystem services. AMBIO, Vol. 45. No. 4. 387-397. o. https://doi.org/10.1007/s13280-016-0768-7.

Chaudhary, A.-Kastner, T. [2016]: Land use biodiversity impacts embodied in international food trade. Global Environmental Change, Vol. 38. 195-204. o. https://doi. org/10.1016/j.gloenvcha.2016.03.013.

Chen, Z.-Ni, W.-XiA, L.-Zhong, Z. [2019]: Structural decomposition analysis of embodied carbon in trade in the middle reaches of the Yangtze River. Environmental Science and Pollution Research, Vol. 26. No. 1. 816-832. o. https://doi.org/10.1007/s11356-018-3662-y.

Cors, T. A. [2000]: Biosafety and international trade: conflict or convergence? International Journal of Biotechnology, Vol. 2. No. 1. 27-43. o. https://doi.org/10.1504/ IJBT.2000.000124.

Dalin, C.-Rodríguez-Iturbe, I. [2016]: Environmental impacts of food trade via resource use and greenhouse gas emissions. Environmental Research Letters, Vol. 11. No. 3. https:// doi.org/10.1088/1748-9326/11/3/035012. 
DAmodaran, A. [2002]: Conflict of trade-facilitating environmental regulations with biodiversity concerns: The case of coffee-farming units in India. World Development, Vol. 30. No. 7. 1123-1135. o. https://doi.org/10.1016/S0305-750X(02)00037-2.

Dang, Q.-Konar, M. [2018]: Trade Openness and Domestic Water Use. Water Resources Research, Vol. 54. No. 1. 4-18. o. https://doi.org/10.1002/2017WR021102.

De Lange, W. J.-Botha, A. M.-Oberholster, P. J. [2016]: Towards tradable permits for filamentous green algae pollution. Journal of Environmental Management, Vol. 179. 21-30. o. https://doi.org/10.1016/j.jenvman.2016.04.052.

De OcA, G. S. M. [2008]: Quantifying NAFTA environmental impacts: Energy and agriculture. CSERGE Working Paper EDM, No. 2. https://www.econstor.eu/handle/10419/48820.

DeFries, R.-Herold, M.-Verchot, L.-Macedo, M. N.-Shimabukuro, Y. [2013]: Export-oriented deforestation in Mato Grosso: Harbinger or exception for other tropical forests? Philosophical Transactions of the Royal Society B. Biological Sciences, Vol. 368. No. 1619. https://doi.org/10.1098/rstb.2012.0173.

Delgado, J. A.-Shaffer, M. J.-Lal, H.-McKinney, S. P.-Gross, C. M.-Cover, H. [2008]: Assessment of nitrogen losses to the environment with a Nitrogen Trading Tool (NTT). Computers and Electronics in Agriculture, Vol. 63. No. 2. 193-206. o. https://doi. org/10.1016/j.compag.2008.02.009.

Drabo, A. [2017]: Climate change mitigation and agricultural development models: Primary commodity exports or local consumption production? Ecological Economics, Vol. 137. 110-125. o. https://doi.org/10.1016/j.ecolecon.2017.03.014.

Eickhout, B.-Van Meijl, H.-Tabeau, A.-Van Rheenen, T. [2007]: Economic and ecological consequences of four European land use scenarios. Land Use Policy, Vol. 24. No. 3. 562-575. o. https://doi.org/10.1016/j.landusepol.2006.01.004.

ERvin, D. E. [1993]: Trade agreements, agriculture, and the environment in developing countries: Discussion. American Journal of Agricultural Economics, Vol. 75. No. 3. 799-800. o. https://doi.org/10.2307/1243595.

FAO [2018]: The State of Agricultural Commodity Markets. Agricultural trade, climate change and food security. Róma, http://www.fao.org/3/I9542EN/i9542en.pdf.

Flachsbarth, I.-Willa arts, B.-Xie, H.-Pitois, G.-Mueller, N. D.-Ringler, C.GARrido, A. [2015]: The role of Latin America's land and water resources for global food security: Environmental trade-offs of future food production pathways. Plos One, Vol. 10. No. 1. https://doi.org/10.1371/journal.pone.0116733.

Garsous, G. [2019]: Trends in policy indicators on trade and environment. OECD Trade and Environment Working Papers, No. 1. https://dx.doi.org/10.1787/b8d2bcac-en.

Hallstrom, D. G. [2004]: Interannual climate variation, climate prediction, and agricultural trade: The costs of surprise versus variability. Review of International Economics, Vol. 12. No. 3. 441-455. o. https://doi.org/10.1111/j.1467-9396.2004.00460.x.

Hanley, N.-Brennan, D. [2012]: Economics of a low-carbon future. Earth and Environmental Science Transactions of the Royal Society of Edinburgh, Vol. 103. No. 2. 149-156. o. https://doi.org/10.1017/S1755691013000042.

Harris, J. M. [2004]: Trade and the Environment. A GDAE Teaching Module on Social and Environmental Issues in Economics. Global Development and Environment Institute, Tufts University, Medford, MA, https:/www.bu.edu/eci/files/2019/06/Trade_and_the_ Environment.pdf.

Hassan, R. M. [1997]: Trade liberalisation and the environment: the case of agriculture in South Africa. Agrekon, Vol. 36. No. 4. 407-433. o. https://doi.org/10.1080/03031853.1997.9523471. 
Henders, S.-Persson, U. M.-Kastner, T. [2015]: Trading forests: land-use change and carbon emissions embodied in production and exports of forest-risk commodities. Environmental Research Letters, Vol. 10. No. 12. https://doi.org/10.1088/1748-9326/10/12/125012.

Iriarte, A.-Almeida, M. G.-Villalobos, P. [2014]: Carbon footprint of premium quality export bananas: Case study in Ecuador, the world's largest exporter. Science of the Total Environment, Vol. 472. 1082-1088. o. http://dx.doi.org/10.1016/j.scitotenv.2013.11.072.

JeBLI, B. M.-YousseF, B. S. [2017]: Renewable energy consumption and agriculture: evidence for cointegration and Granger causality for Tunisian economy. International Journal of Sustainable Development and World Ecology, Vol. 24. No. 2. 149-158. o. https://doi.org/ 10.1080/13504509.2016.1196467.

Johansson, R. C.-Cooper, J.-Peters, M. [2006]: An agri-environmental assessment of trade liberalization. Ecological Economics, Vol. 58. No. 1.37-48. o. https://doi.org/10.1016/ j.ecolecon.2005.05.018.

LeE, D. J.-Zhang, J. [2009]: Efficiency, equity, and environmental implications of trade liberalization: A computable general equilibrium analysis. The Journal of International Trade and Economic Development, Vol. 18. No. 3. 347-371. o. https://doi. org/10.1080/09638190902986504.

Leitao, N. C. [2011]: Environmental change and agriculture: The role of international trade. African Journal of Agricultural Research, Vol. 6. No. 17. 4065-4068. o. https://doi. org/10.5897/AJAR11.1384.

Malak-Rawlikowska, A.-Majewski, E.-Wąs, A.-Borgen, S. O.-Csillag Péter-Donati, M.-Freeman, R.-HoÀng, V.-Lecoeur, J.-L.-Mancini, M. C.-Nguyen, A.-SaÏdi, M.Tocco, B.-Török Áron-Veneziani, M.-Vittersø, G.-Wavresky, P. [2019]: Measuring the Economic, Environmental, and Social Sustainability of Short Food Supply Chains. Sustainability, Vol. 11. No. 15. https://doi.org/10.3390/su11154004.

Martinez-Melendez, L. A.-Bennett, E. M. [2016]: Trade in the US and Mexico helps reduce environmental costs of agriculture. Environmental Research Letters, Vol. 11. No. 5. https://doi.org/10.1088/1748-9326/11/5/055004.

Moher, D.-Liberati, A.-Tetzlaff, J.-Altman, D. G. [2009]: The PRISMA Group Preferred Reporting Items for Systematic Reviews and Meta Analyses: The PRISMA Statement. https://doi.org/10.1371/journal.pmed1000097.

Moon, W. [2011]: Is agriculture compatible with free trade? Ecological Economics, Vol. 71. 13-24. o. https://doi.org/10.1016/j.ecolecon.2011.09.004.

Nesme, T.-Metson, G. S.-Bennett, E. M. [2018]: Global phosphorus flows through agricultural trade. Global Environmental Change, Vol. 50. 133-141. o. http://dx.doi.org/10.1016/j. gloenvcha.2018.04.004.

OECD [2019]: Trade and the environment. How are trade and environmental sustainability compatible? https://www.oecd.org/trade/topics/trade-and-the-environment/.

Rauf, A.-Zhang, J.-Li, J.-Amin, W. [2018]: Structural changes, energy consumption and carbon emissions in China: Empirical evidence from ARDL bound testing model. Structural Change and Economic Dynamics, Vol. 47. 194-206. o. https://doi.org/10.1016/ j.strueco.2018.08.010.

Saikku, L.-Soimakallio, S.- Pingoud, K. [2012]: Attributing land-use change carbon emissions to exported biomass. Environmental Impact Assessment Review, Vol. 37. 47-54. o. https://doi.org/10.1016/j.eiar.2012.03.006.

SAunders, C.-Wreford, A.-Cagatay, S. [2006]: Trade liberalisation and greenhouse gas emissions: the case of dairying in the European Union and New Zealand. The Australian 
Journal of Agricultural and Resource Economics, Vol. 50. 538-555. o. https://doi. org/10.1111/j.1467-8489.2006.00343.x.

Schmitz, C.-Lotze-Campen, H.-Gerten, D.-Dietrich, J. P.-Bodirsky, B.-Biewald, A.Popp, A. [2013]: Blue water scarcity and the economic impacts of future agricultural trade and demand. Water Resources Research, Vol. 49. 3601-3607. o. https://doi.org/10.1002/ wrcr. 20188.

Schmitz, C.-Kreidenweis, U.-Lotze-Campen, H.-Popp, A.-Krause, M.-Dietrich, J. P.Muller, C. [2015]: Agricultural trade and tropical deforestation: interactions and related policy options. Regional Environmental Change, Vol. 15. 1757-1772. o. https://oi.org/10.1007/ s10113-014-0700-2.

Török ÁroN-AgÁRDI Irma [2020]: Társadalmi vállalkozások gasztronómiai lehetőségei a rövid élelmiszer-ellátási láncok bevonásával Magyarországon. Vezetéstudomány, Vol. 51. No. 4. 74-84. o. http://dx.doi.org/10.14267/veztud.2020.04.07.

WALters, B. B. [2017]: Explaining rural land use change and reforestation: A causal-historical approach. Land Use Policy, Vol. 67. 608-624. o. http://dx.doi.org/10.1016/j.landusepol. 2017.07.008.

Weinzettel, J.-Wood, R. [2018]: Environmental Footprints of Agriculture Embodied in International Trade: Sensitivity of Harvested Area Footprint of Chinese Exports. Ecological Economics, Vol. 145. 323-330. o. https://doi.org/10.1016/j.ecolecon.2017.11.013.

WTO [2018]: World trade statistical review 2018. World Trade Organization. https://www. wto.org/english/res_e/statis_e/wts2018_e/wts2018_e.pdf.

WTO [2019]: World trade statistical review 2019. World Trade Organization. https://www. wto.org/english/res_e/statis_e/wts2019_e/wts2019_e.pdf.

YAU, Y. Y.-Thibodaeu, B.-Not, C. [2018]: Impact of cutting meat intake on hidden greenhouse gas emissions in an import-reliant city. Environmental Research Letters, Vol. 13. No. 6. http://dx.doi.org/10.1088/1748-9326/aabd45.

Zhang, Z. Y.-YAng, H.-Shi, M. J.-Zehnder, A. J. B.-Abbaspour, K. C. [2011]: Analyses of impacts of China's international trade on its water resources and uses. Hydrology and Earth System Sciences, Vol. 15. 2871-2880. o. https://doi.org/10.5194/hess-15-2871-2011.

ZhaO, X.-YAng, H.-YAng, Z.-Chen, B.-Qin, Y. [2010]: Applying the Input-Output Method to Account for Water Footprint and Virtual Water Trade in the Haihe River Basin in China. Environmental Science and Technology, Vol. 44. No. 23. 9150-9156. o. https://dx.doi. org/10.1021/es100886r. 